*aMIS View/Print Document Cover Sheet

This document was retrieved from the Boeing ISEARCH System.

Accession \#: D196054906

Document \#: SD-WM-ER-505

Title/Desc:

TANK 241A101 HEADSPACE GAS \& VAPOR CHARACTERIZATION RESULTS FOR SAMPLES COLLEDTED IN $6 / 1995$ 


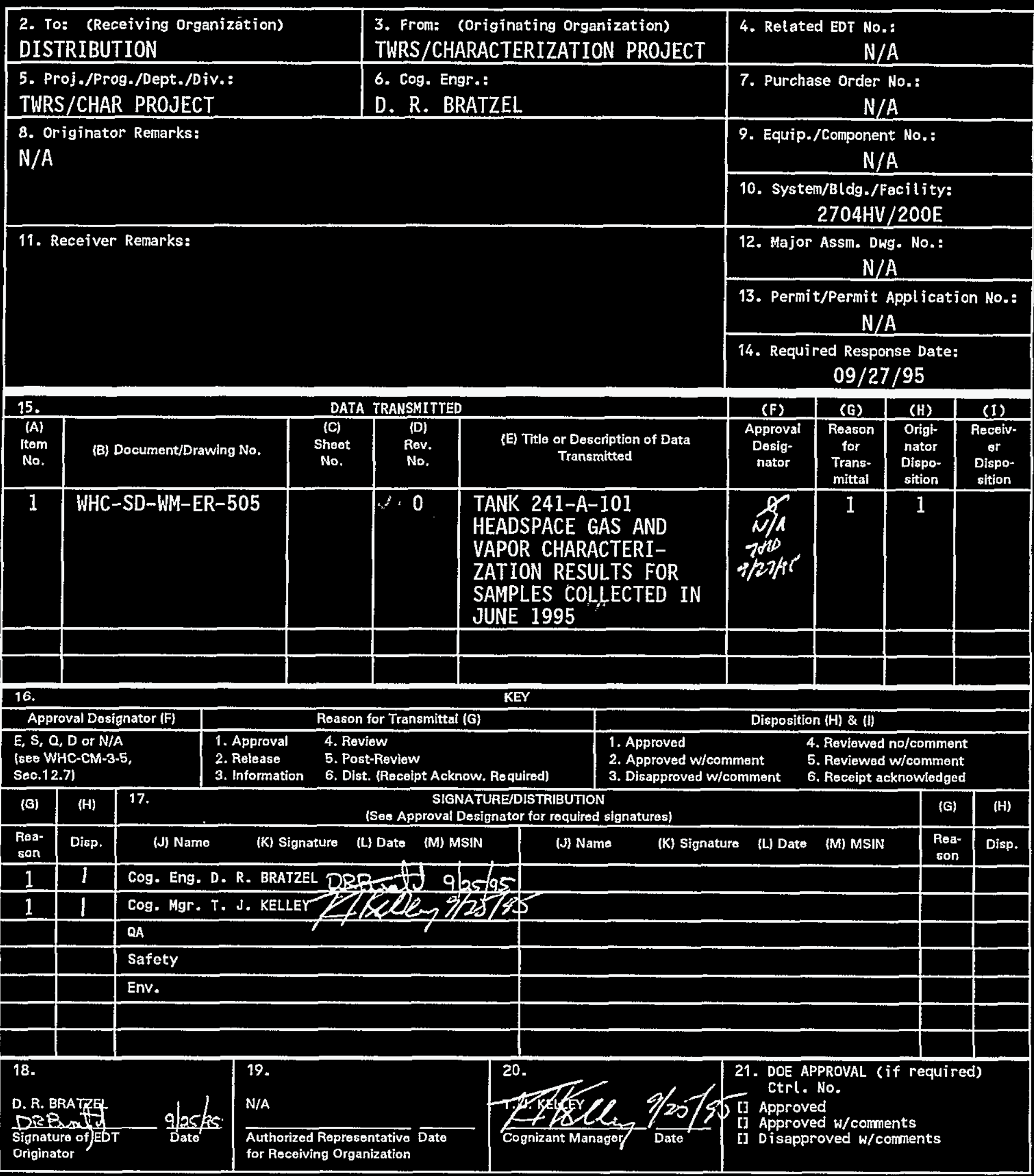




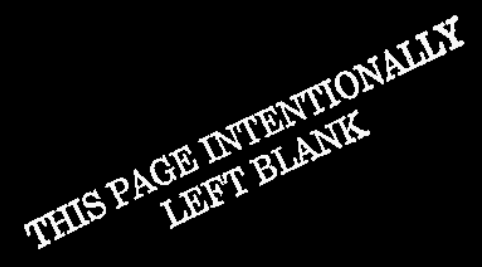




\section{RELEASE AUTHORIZATION}

Document Number: WHC-SD-WM-ER-505, REV 0

Document Title: Tank 241-A-101 Headspace Gas and Vapor

Characterization Results for Samples Collected in June 1995

Release Date: $\quad 9 / 28 / 95$

This document was reviewed following the procedures described in WHC-CM-3-4 and is:

APPROVED FOR PUBLIC RELEASE

WHC Information Release Administration Specialist:
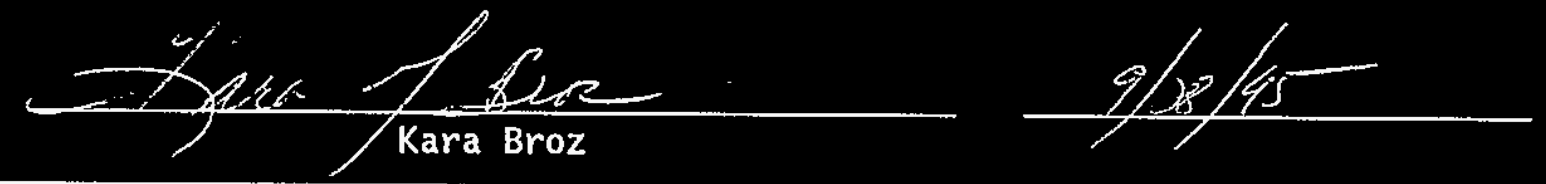

TRADEMARK DISCLAIMER. Reference herein to any specific commercial product, process, or service by trade name, trademark, manufacturer, or otherwise, does not necessarily constitute or imply its endorsement, recommendation, or favoring by the United States Government or any agency thereof or its contractors or subcontractors.

This report has been reproduced from the best available copy. Available in paper copy. Printed in the United States of America. To obtain copies of this report, contact:

Westinghouse Hanford Company - Document Control Services

P.0. Box 1970, Mailstop H6-08, Richland, WA 99352

Telephone: (509) 372-2420; Fax: (509) 376-4989 
$-$ 


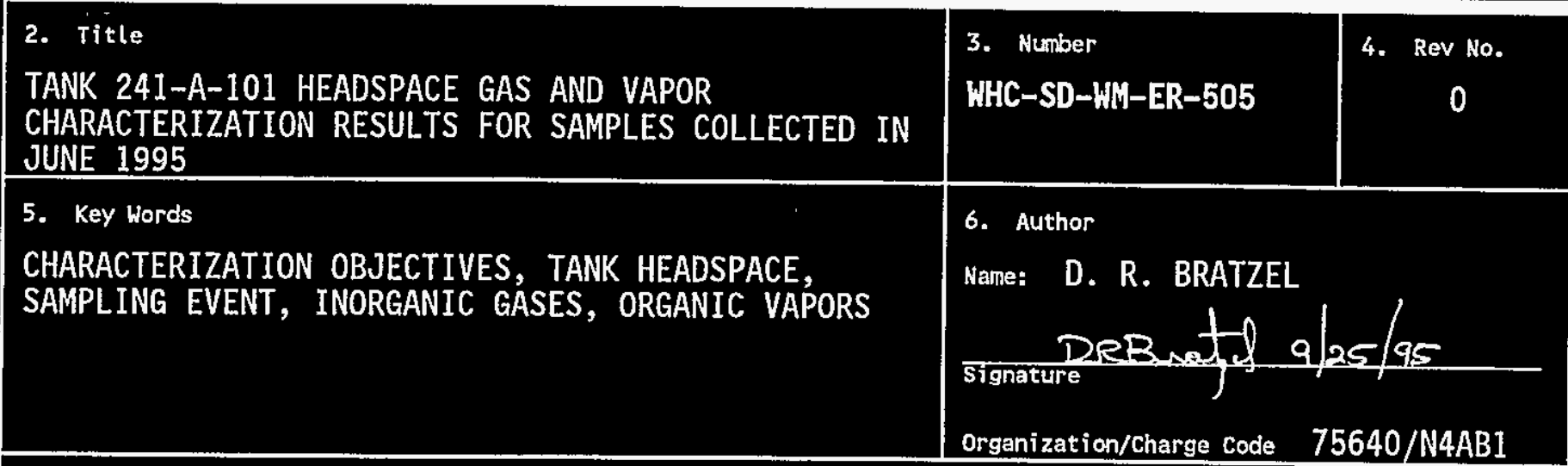

7. Abstract

Significant changes have been made to all of the original vapor characterization reports. This report documents specific headspace gas and vapor characterization results for all vapor sampling events to date. In addition, changes have been made to the original vapor reports to qualify the data based on quality assurance issues associated with the performing laboratories. 


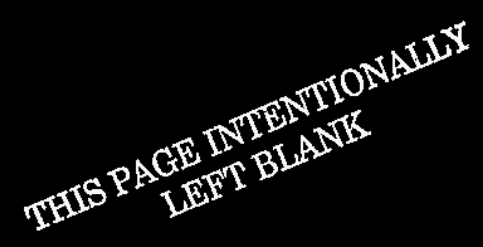


WHC-SD-WM-ER-505

Revision 0

UC-2070

\title{
Tank 241-A-101 Headspace Gas and Vapor Characterization Results for Samples Collected in June 1995
}

\author{
J. L. Huckaby \\ Pacific Northwest Laboratories \\ D. R. Bratzel \\ Westinghouse Fanford Company
}

Date Published

September 1995

Prepared for the U.S. Department of Energy Office of Environmental Restoration and Waste Management

$\begin{array}{ll}\text { Westinghouse } & \text { P.O Box } 1970 \\ \text { Hanford Company } & \text { Richland, Weshington }\end{array}$

Management and Operations Coniractor for the

U.S. Department of Energy under Contract DE-AC06.87FL 10930

Approved for Public Release 
THIS PAGE INTENTIONALLY

LEFT BLANK 


\section{Contents}

1.0 INTRODUCTION

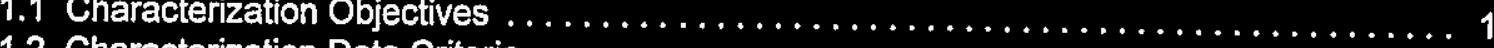

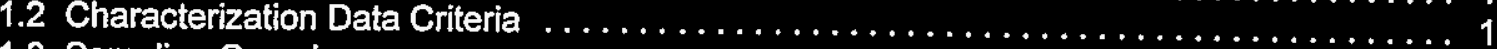

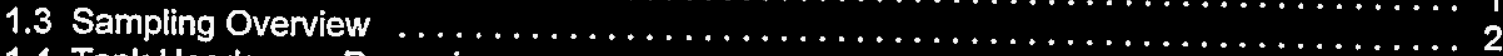

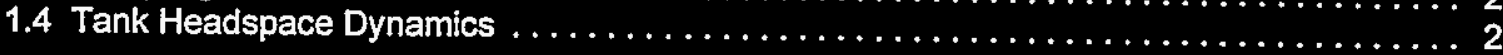

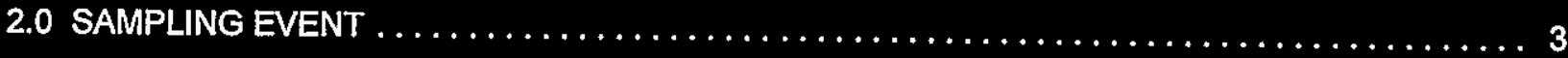

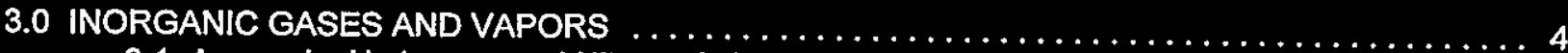

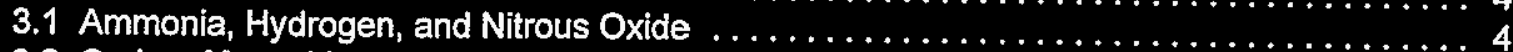

3.2 Carbon Monoxide and Carbon Dioxide $\ldots \ldots \ldots \ldots \ldots \ldots \ldots \ldots \ldots \ldots \ldots$

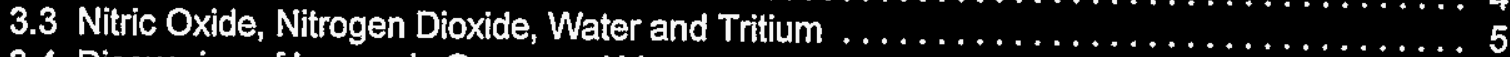

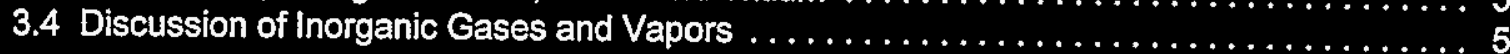

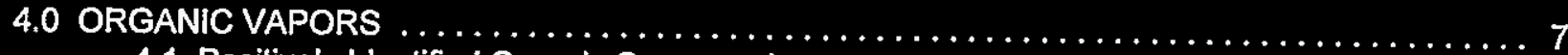

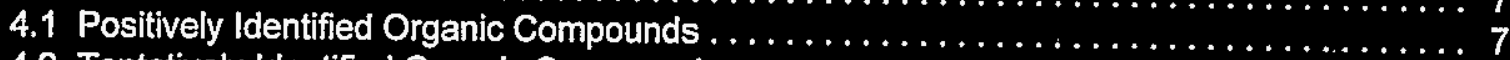

4.2 Tentatively Identified Organic Compounds $\ldots \ldots \ldots \ldots \ldots \ldots \ldots \ldots \ldots \ldots$

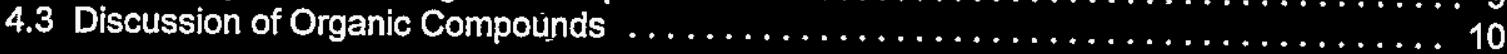

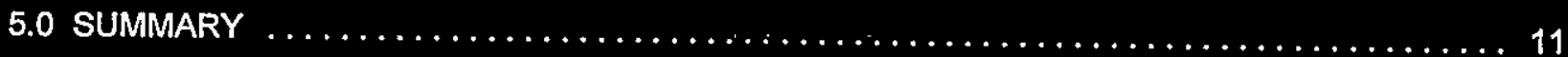

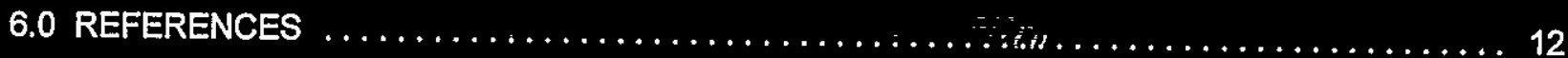

\section{Acronyms and Abbreviations}

$\begin{array}{ll}\text { CES } & \text { consensus exposure standard } \\ \text { EPA } & \text { Environmental Protection Agency } \\ \text { GC } & \text { gas chromatograph } \\ \text { GC/MS } & \text { gas chromatograph/mass spectrometer } \\ \text { LFL } & \text { lower flammability limit } \\ \text { MS } & \text { mass spectrometer } \\ \text { NFPA } & \text { National Fire Protection Association } \\ \text { NPH } & \text { normal paraffinic hydrocarbon } \\ \text { ORNL } & \text { Oak Ridge National Laboratory } \\ \text { PNL } & \text { Pacific Northwest Laboratory } \\ \text { ppmv } & \text { parts per million by volume, } 1 \text { ppmv = 10.4 vol\% } \\ \text { TO-14 } & \text { task order } 14 \\ \text { TST } & \text { triple sorbent trap } \\ \text { vol\% } & \text { percent by volume, } 1 \text { vol\% }=10,000 \text { ppmv } \\ \text { VSS } & \text { vapor sampling system } \cdot \\ \text { WHC } & \text { Westinghouse Hanford Company }\end{array}$

Acknowledgements

The authors wish to thank Chris Simonen for her work verifying data and generating tables, and Shas Mattigod for his help with the construction and reviews of this document. The authors also wish to thank Luther Buckley, Clarence Homi, and Tom Kunthara for their contributions to the final reviews and publication of this document. 

WHC-SD-WM-ER-505 Rev. 0

Tank 241-A-101 Headspace Gas and Vapor Characterization Results

for Samples Collected in June 1995

\subsection{INTRODUCTION}

\subsection{Characterization Objectives}

Tank A-101 headspace gas and vapor samples were collected and analyzed to help determine the potential risks of fugitive emissions to tank farm workers. The drivers and objectives of waste tank headspace sampling and analysis are discussed in Program Plan for the Resolution of Tank Vapor Issues (Osborne and Huckaby 1994). Tank A-101 was vapor sampled in accordance with Data Quality Objectives for Generic In-Tank Health and Safety lssue Resolution (Osborne et al. 1995).

\subsection{Characterization Data Criteria}

Data Quality Objectives for Generic In-Tank Health and Safety Issue Resolution describes parameters for data collection to ensure appropriate conclusions can be drawn from the data. Tank headspace characterization data were collected to help in the evaluation of 1) headspace flammability, and 2) identification and quantification of compounds of toxicological concern.

Single Shell Tank Interim Operational Safety Requirements (Dougherty 1995) specifies that combustible constituents in tank headspaces be maintained below $25 \%$ of the lower flammability limit (LFL). This essentially agrees with National Fire Protection Association requirements that combustible concentrations be maintained at or below $25 \%$ of the LFL (NFPA 1994). However, current governing operating specifications for Watchlist waste tanks, such as tank A-101 specify that combustible constituents be maintained at or below $20 \%$ of the LFL (WHC 1995a).

Headspace characterization data is used by Westinghouse Hanford Company (WHC) Tank Waste Remediation Systems Industrial Hygiene as source term data in the industrial hygiene strategy to protect workers from tarik fugitive emissions. Because selection of worker protective equipment must be based on industrial hygiene monitoring of the work place and not on source term data (29 CFR 1910.120), tank headspace characterization data can not be used for this purpose. Furthermore, because there are mechanisms by which headspace constituents can be either diluted or concentrated as they are released to the atmosphere, the headspace characterization data should not be considered to be representative of emissions at the point of emission.

These statements notwithstanding, the data quality objectives document specifies that the industrial hygiene group be advised if constituents with toxicological properties exceed $50 \%$ of the appropriate consensus exposure standard (CES) for non-carcinogens, or $10 \%$ of the appropriate CES for carcinogens. A CES is defined as the most stringent of known regulatory or recommended toxicological values for the workplace (Osborne et al. 1995). 


\subsection{Sampling Overview}

Tank headspace characterization data presented here are from a single sampling event. Samples . collected are thought to have been representative of tank A-101 headspace when the tank was sampled (Meacham et al. 1995), and samples analyses were designed to provide a reasonably accurate and complete characterization of the significant headspace constituents. No assessment has been made as to how the tank A-101 headspace composition changes with time, though studies of tank C-103 suggest that composition changes probably occur very slowly in the passively ventilated tanks (Huckaby and Story 1994)

\subsection{Tank Headspace Dynamics}

Tank A-101 is the first tank in a 3-tank cascade with tanks A-102 and A-103. It is connected to tank A-102 via a 7.4-cm (2.9-in.) inside diameter, 7.6-m (25-it) long underground cascade line. A similar line connects tanks A-102 and A-103. Since these cascade lines connect the headspaces of these tanks, gases and vapors originating from the wastes in tank A-102 or tank A-103 may be transferred to tank A-101 (unless the cascade lines are obstructed). At this time, however, no headspace characterization data is available for tank A-102 or A-103 to assess their potential transfer of gases and vapors to tank A-101.

The cascade of tanks A-101, A-102, and A-103 is passively ventilated, which means that the tanks are allowed to exhale air, waste gases, and vapors as the barometric pressure falls, and inhale ambient air as the barometric pressure rises. Each of these tanks has its own filtered breather riser. Barometric pressure typically rises and falls on a diurnal cycle, producing an average daily exchange of air equal to about $0.46 \%$ of each tank headspace (Huckaby 1994). Changes in the concentrations of tank headspace constituents due to barometric pressure changes are consequently very slow. 


\subsection{SAMPLING EVENT}

Headspace gas and vapor samples were collected from tank A-101 using the vapor sampling system (VSS) on June 8, 1995 by WHC Sampling and Mobile Laboratories (WHC 1995b). Sample collection and analysis were performed as directed by Tank 241-A-101 Tank Characterization Plan (Homi 1995a). The tank headspace temperature was determined to be $37^{\circ} \mathrm{C}$. Air from the A-101 headspace was withdrawn from a single elevation via a $6.7-\mathrm{m}$ long heated sampling probe mounted in riser 20 , and transferred via heated tubing to the VSS sampling manifold. All heated zones of the VSS were maintained at approximately $60^{\circ} \mathrm{C}$. All tank air samples were collected between $11: 16$ a.m. and 1:44 p.m., with no anomalies noted.

Sampling media were prepared and analyzed by WHC, Oak Ridge National Laboratories (ORNL), and Pacific Northwest Laboratories (PNL). The 52 tank air samples and 2 ambient air control samples collected are listed in Table 2-1 by analytical laboratory. Table 2-1 also lists the 16 trip blanks and 4 field blanks provided by the laboratories.

A general description of vapor sampling and sample analysis methods has been given by Huckaby et al. (1995). The sampling equipment, sample collection sequence, sorbent trap sample air flow rates and flow times, chain of custody information, and a discussion of the sampling event itself are given in WHC 1995b. 


\subsection{INORGANIC GASES AND VAPORS}

Analytical results of sorbent trap and SUMMA ${ }^{\mathrm{TM}, 1}$ canister tank air samples for selected inorganic gases and vapors are given in Table 3-1 in parts per million by volume (ppmv). Inorganic analyte sorbent traps were prepared and analyzed by PNL, with analyses performed within 11 days of sample collection (Pool et al. 1995). Analyses of SUMMA ${ }^{T M}$ canisters for inorganic compounds were performed 12 days after sample collection, thus meeting the 60-day holding time requirement of the WHC quality assurance project plan (Keller 1994). It should be noted that these inorganic compounds (i.e., the permanent gases) would be expected to be very stable in the SUMMATM canisters, and the results may not have been affected even if the 60 day holding time requirements had been exceeded. Sample preparation and analyses were performed at PNL quality assurance impact level 2.

\subsection{Ammonia, Hydrogen, and Nitrous Oxide}

The concentration of ammonia in the headspace of tank A-101 was determined to be 754 ppmv from 6 sorbent trap samples. Ammonia has been observed in virtually all of the passively ventilated waste tanks sampled to date, at concentrations ranging from about 3 ppmv in tank C-108 (Lucke et al. 1995), to 1040 ppmv in BY-108 (McVeety et al. 1995). Given the LFL of ammonia in air is about $15 \%$ by volume (vol\%), the measured $754 \mathrm{ppmv}$ corresponds to about $0.5 \%$ of the LFL, and does not contribute appreciably to the flammability of the headspace.

The concentration of hydrogen in tank A-101, determined to be 758 ppmv from 3 SUMMA ${ }^{\text {TM }}$ canister samples, is the highest measured in any passively ventilated waste tank that has been sampled. Hydrogen in the waste tanks is of concern as a fuel. Given that the LFL for hydrogen in air is about 4 vol\%, the 758 ppmv hydrogen concentration in tank A-101 corresponds to about $1.9 \%$ of its LFL. At this level, hydrogen is not a flammability concern in tank A-101.

The nitrous oxide concentration in tank A-101 was determined to be 218 ppmv from 3 SUMMA ${ }^{\text {TM }}$ canister samples. Nitrous oxide has been detected in other passively ventilated waste tanks at average concentrations as low as about 12 ppmv in tank TX-105 (Klinger et al. 1995), and as high as 878 ppmv in tank U-103 (Ligotke et al. 1995). Under proper conditions, nitrous oxide can serve as an oxidizer to support combustion. However, Cashdollar et al. (1992) found that nitrous oxide had no significant effect on the fiammability of hydrogen and air mixtures for hydrogen concentrations less than $20 \mathrm{vol} \%$, and that "small amounts of nitrous oxide (relative to air) do not appear to have much effect on the flammability". Their results suggest the measured nitrous oxide concentration is much too low to have a significant effect on the flammability of the tank A-101 headspace.

\subsection{Carbon Monoxide and Carbon Dioxide}

Carbon monoxide in the tank A-101 headspace was reported as < 12 ppmv In ambient air it typically ranges from 0.05 to $0.15 \mathrm{ppmv}$. Because different analytical methods have been used to measure carbon monoxide in the waste tanks sampled to date, the information on carbon monoxide has varied from tank to tank. However, elevated waste tank headspace carbon monoxide concentrations are common, and are thought to be due to the decomposition of organic waste in the tanks. Carbon monoxide has not been

${ }^{1}$ SUMMA is a trademark of Molectrics, Inc., Cleveland, Ohio. 
measured at very high levels in any of the waste tanks, the highest level measured to date was [26.7 ppmv] in tank C-1032 (Huckaby and Story 1994).

The carbon dioxide concentration in the tank A-101 headspace, measured to be $<23$ ppmv, is significantly lower than it is in ambient air. Carbon dioxide introduced by air exchange with the atmosphere is readily absorbed by caustic supernatant and interstitial liquids of the waste tanks, and converted to carbonate in solution. Carbon dioxide is normally present in the ambient air at a concentration of 350 to $400 \mathrm{ppmv}$, and is typically lower than ambient in the waste tank headspaces. The ambient air samples collected at the start of the tank A-101 sampling event, for example, contained an average 343 ppmv of carbon dioxide. The carbon dioxide in tank A-101, at < 23 ppmv, is typical of its value in other waste tanks sampled to date.

\subsection{Nitric Oxide, Nitrogen Dioxide, Water and Tritium}

Nitric oxide and nitrogen dioxide.concentrations in the tank A-101 headspace were determined to be $\leq$ 0.09 and $\leq 0.01$ ppmv, respectively. These are acid gases that would have very low equilibrium concentrations above the high pH sludge in tank A-101. The measurable presence of nitric oxide is not uncommon in the waste tank headspaces, and may be due to its formation from oxygen and nitrogen in the radiation field of the headspace. These constituents could potentially serve as oxidizers to support combustion, but at the measured concentrations would have a negligible effect on the flammability of the tank A-101 headspace.

The water vapor concentration of tank A-101 was determined to be about $22.3 \mathrm{mg} / \mathrm{L}$, at the measured tank headspace temperature of $37^{\circ} \mathrm{C}$ and pressure of $989 \mathrm{mbar}$ (742 torr), (WHC 1995b). This corresponds to a water vapor partial pressure of 31.9 mbar $\left(23.9\right.$ torr), to a dew point of $25.1^{\circ} \mathrm{C}$, and to a relative humidity of $51 \%$.

Silica gel sorbent traps were used to test for tritium. It is assumed that tritium produced by the waste combines with hydroxide ions to form tritium-substituted water. Evaporation of the tritium-substituted water would then result in airborne radioactive contamination. Silica gel sorbent traps adsorb virtually all (normal and tritium-substituted) water vapor from the sampled tank air, and are analyzed at the WHC 222$S$ laboratory. Radiochemical analysis of the silica gel trap indicated the total activity of the headspace to be less than $50 \mathrm{pCi} / \mathrm{L}$ (WHC 1995b).

\subsection{Discussion of Inorganic Gases and Vapors}

Aside from water vapor, the most abundant waste constituents in the tank A-101 headspace are hydrogen, ammonia, and nitrous oxide. These gases have been detected in most tank headspaces sampled to date, and are usually the dominant species. The concentrations of hydrogen and ammonia are higher in tank A-101 than in most other passively ventilated waste tanks that have been sampled.

The relative standard deviations of the inorganic gas and vapor results given in the last column in Table 31 are excellent for the methods used. Relative standard deviations range from about $0.5 \%$ for nitrous oxide to about $3.8 \%$ for ammonia. Because the precision reported depends both on sampling parameters

\footnotetext{
2 The carbon monoxide measurement in tank C-103 was made by Oregon Graduate Institute of Science and Technology, and placed in brackets to emphasize it should be considered secondary data.
} 


\section{WHC-SD-WM-ER-505 Rev, 0}

(e.g., sample flow rate and flow time for sorbent traps) and analytical parameters (e.g., sample preparation, dilutions, etc.), small relative standard deviations suggest proper control was maintained both in the field and in the laboratories. 
WHC-SD-WM-ER-505 Rev. 0

\subsection{ORGANIC VAPORS}

Organic vapors in the tank A-101 headspace were sampled using SUMMA ${ }^{\text {TM }}$ canisters, which were analyzed by PNL, and triple sorbent traps (TSTs), which were analyzed by PNL and ORNL. To the extent possible, identical sets of TSTs were collected for PNL and ORNL, though each laboratory prepared their own samples. Both PNL and ORNL used gas chromatograph (GC) equipped with a mass spectrometer (MS) to separate, identify, and quantitate the analytes. Descriptions of sample device cleaning, sample preparations, and analyses are given by Jenkins et al. (1995) and Pool et al. (1995).

PNL SUMMA ${ }^{\mathrm{TM}}$ and TST results should be considered to be the primary organic vapor data for tank A101. SUMMA ${ }^{\mathrm{TM}}$ canister and TST samples were prepared and analyzed at PNL quality assurance impact level 2 and 3, respectively. PNL analyses of TSTs and SUMMA ${ }^{T M}$ canisters for organic vapors were completed 32 and 12 days, respectively, after sample collection. These satisfied the administratively chosen 60-day holding time (Keller 1994). PNL has not conducted holding time studies to determine the stability of organic compounds in either SUMMA ${ }^{\text {TM }}$ canisters or TSTs in the chemical matrix of the tank air samples.

ORNL analyses of TST samples from this and other waste tanks generally agree with, support, and augment the SUMMATM sample results. However, because certain WHC quality assurance requirements were not satisfied by ORNL, the quality assurance assessment of ORNL by Hendrickson (1995) should be reviewed before results unique to the TST samples are used for decision making.

All TSTs prepared by ORNL had 3 surrogate compounds added to evaluate sample matrix effects, potential handling, storage, and shipment problems, and analytical instrumentation performance (Jenkins et al. 1995). ORNL evaluated the surrogate recoveries using a statistical approach similar to that prescribed by SW 846 Method 8260 A Volatile Organic Compounds by Gas Chromatography/Mass Spectrometry (GCMS) Capillary Column Technique (EPA 1992). Using this approach, ORNL reported that all surrogates had standard deviation values within the $95 \%$ confidence interval for variance, indicating that no bias was introduced in the measurement of analyte quantities.

PNL used the same number and type of surrogate spikes as were used by ORNL. Surrogate recoveries by PNL were comparable to those of ORNL, but the ORNL. statistical criteria are not directly applicable. A statistical treatment of PNL surrogate recoveries, similar to that done by ORNL, has not been performed in part because of insufficient data. Surrogates have been used by PNL only as indicators of gross sample matrix, handling, storage, or shipment problems, and no such problems were indicated in the tank A-101 TST samples.

\subsection{Positively Identiffed Organic Compounds}

Positive identification of organic analytes using the methods employed by PNL and ORNL. involves matching the GC retention times and MS data from a sample with that obtained from the analysis of standards. The concentration of an analyte in the sample is said to be quantitatively measured if the response of the GC/MS has been established at several known concentrations of that analyte (i.e., the GC/MS has been calibrated for that analyte), and the MS response to the analyte in the sample is between the lowest and highest responses to the known concentrations (i.e., the analyte is within the calibration range).

ORNL and PNL were assigned different lists of organic compounds, or target analytes, to positively identify and measure quantitatively. The ORNL target analyte list was derived from a review of the tank C- 


\section{WHC-SD-WM-ER-505 Rev. 0}

103 headspace constituents by a panel of toxicology experts (Mahlum et al. 1994). The PNL target analyte list included 39 compounds from the Environmental Protection Agency (EPA) task order 14 (TO14) method, which are primarily halocarbons and common industrial solvents (EPA 1988), plus 14 analytes selected mainly from the toxicology panel's review of tank $\mathbf{C}-103$. For cost efficiencies, PNL analyzed for the same set of target analytes in both SUMMA ${ }^{\text {TM }}$ and TST samples. This was also done to obtain maximum comparison of the methods.

Table 4-1 lists the organic compounds positively identified and quantitated in SUMMA ${ }^{\mathrm{TM}}$ samples. SUMMA ${ }^{T M}$ analyses were performed according to the TO-14 methodology, except for analysis of methane, which was analyzed with the inorganic gases (Pool et al. 1995). Only 6 of the 39 TO-14 target analytes and 8 of the 14 additional target analytes were measured to be above the 0.005 ppmv detection limit of the analyses. Averages reported are from analyses of 3 SUMMA ${ }^{\text {TM }}$ canister samples. The precision of the SUMMA ${ }^{\mathrm{TM}}$ sample measurements was exceptionally good, as indicated by the very small relative standard deviations given in the last column of Table 4-1.

The positively identified and quantitated analytes in PNL TST samples, with their average concentrations, are listed in Table 4-2. These are also given with the analogous PNL SUMMA ${ }^{\text {TM }}$ canister results in Table 4-3 for comparison. In general, the agreement between these 2 methods is quite good. All target analytes detected in SUMMA ${ }^{\mathrm{TM}}$ samples were also detected in TST samples by PNL, and 5 compounds were positively identified in TST samples by PNL that were not detected (at or above 0.005 ppmv) in SUMMA ${ }^{\text {TM }}$ samples. The largest discrepancy between the 2 methods is for the measurement of propanone (acetone), which was detected in SUMMA ${ }^{\mathrm{TM}}$ samples at an average $0.72 \mathrm{ppmV}$, and in TST samples at only 0.18 ppmv.

Jenkins et al. (1995) report the positive identification of 26 of 27 target analytes in TST samples. Dichloromethane was the only TST target analyte not detected. Despite calibration of the instrument over about a 20-fold concentration range, oniy 11 of the target analytes were measured to be within the calibration range in all 3 TST samples. The average concentrations of these 11 quantitated target analytes are given in Table 4-4. Tables $4-5$ and $4-6$ give the average concentrations of 13 compounds which were positively identified but not quantitated because their measured concentration was not within the instrument calibration range in at least 1 TST sample. Separated in Table 4-6 are the 2 compounds for which the analyte-specific ORNL practical holding times had been exceeded. Data in Tables 4-5 and 4-6 may not be accurate to within $\pm 30 \%$ as specified by Burnum (1995).

The ORNL practical holding time is defined as the holding time for which there is a $15 \%$ risk that the concentration of an analyte in the sample will be below its initial concentration (Jenkins et al. 1995). The 2 compounds listed in Table 4-6, butanal and 1-butanol, had exceeded their practical holding times when the samples were analyzed 19 days after being collected. It should be noted that the analyses were performed within 6 days of receipt of samples by ORNL, and that butanal, for example, has a practical holding time of only 1 day.

Tributyl phosphate and dibutyl butylphosphonate were both positively identified by ORNL in the TST samples, but because calibration of the instrument for these compounds requires special procedures and these compounds have known sampling problems, quantitation was not attempted. ORNL also reported significant discrepancies in the amounts of tributyl phosphate and dibutyl phosphate measured on the TSTs which indicated analyte-specific sampling problems.

Both PNL and ORNL report target analyte concentrations in ppmv of analyte in dry air. To correct for the measured water vapor content of tank A-101 and obtain concentration in ppmv of analyte in moist tank air, multiply by 0.969 . 
PNL and ORNL TST samples were collected in a manner to minimize inter-laboratory differences. Specifically, identical sample volumes were drawn through like sets of TSTs (though the design of the TSTs used by the 2 laboratories is slightly different), and they were collected simultaneously, from alternate locations of the sorbent trap sampling station of the VSS. Table 4-7 lists the 10 target analytes that were common to both ORNL and PNL analyses, with their measured concentrations in PNL SUMMA ${ }^{\text {TM }}$ samples, PNL TST samples, and ORNL TST samples. Comparison of the data given in Table 4-7 suggests the 3 sampling and analysis methodologies are in fairly good agreement. Though the results for ethanenitrile and propanenitrile might indicate a difference between the laboratories, and the results for propanone and $n$-butanenitrile might indicate a difference between the sampling devices (or their respective analyses), the data presented are insufficient to draw clear conclusions.

Six positively identified analytes in tank A-101 were measured to be above $0.1 \mathrm{ppmv}$ : 1-butanol, propanone (acetone), ethanenitrile (acetonitrile), 1-propanol, tetrahydrofuran, and $n$-tridecane. At the reported concentrations, these headspace constituents do not individually or collectively represent a flammability hazard.

\subsection{Tentatively Identified Organic Compounds}

In addition to the target analytes, the ORNL and PNL analytical procedures allow the tentative identification of other organic compounds. Tentative identification of analytes was performed by comparing the MS molecular fragmentation patterns with a library of known MS fragmentation patterns. This method allows an organic analyte to be identified (with reasonable certainty) as an alkane, a ketone, an aldehyde, etc., and may also determine its molecular weight. The method usually does not, however, allow the unambiguous identification of structural isomers, and this ambiguity increases with analyte molecular weight. Many analytes can be tentatively identified with reasonable confidence without having to inject standards of each into the GCMS to determine their GC retention times or specific MS patterns.

By the riature of the sampling devices, virtually all organic vapors present in the tank headspace are collected by both TST and SUMMA ${ }^{T M}$ samples. Analyses of the samples are designed to recover, separate, identify, and quantify the organic vapors in the samples. TSTs are not good for collecting highly volatile compounds (i.e., molecules more volatile than propane), but are quite good for most others. In contrast, the recovery of very low volatility compounds (e.g., molecules with more than about 15 carbon atoms) and some polar compounds with moderate volatility (e.g., butanal) from SUMMA ${ }^{\mathrm{TM}}$ samples has been problematic.

The lists of tentatively identified compounds recovered from SUMMA ${ }^{\text {TM }}$ and TST samples with their estimated concentrations, are given in Tables 4-8 and 4-9, respectively. Compounds are listed in Table 46 in the order by which they eluted chromatographically, and only non-zero results are included in the reported averages. The list of tentatively identified compounds detected in TST samples, and their estimated concentrations, is given in Table 4-10. Compounds are listed in Table 4-10 according to the order by which the eluted chromatographically. The averages reported by ORNL in Table 4-10 are all 3sample averages, and if an analyte was not detected in a sample, its concentration in that sample was considered to be zero for averaging purposes. Estimated concentrations are in $\mathrm{mg} / \mathrm{m}^{3}$, based on dry air at $0^{\circ} \mathrm{C}$ and 1.01 bar.

The ORNL and PNL methods used to tentatively identify and estimate concentrations are described by Jenkins et al. (1995) and Pool et al. (1995), respectively, and should be reviewed before this data is used for decision making. Concentrations given in Tables 4-8 through and 4-10 should be considered estimates. 


\subsection{Discussion of Organic Compounds}

Some of the organic compounds identified in the June 1995 tank A-101 headspace samples are apparently from residual organic solvents still present in the tank waste. In particular, the semivolatile straight-chain alkanes were used as diluents of tributyl phosphate in various plutonium extraction processes. These alkanes (i.e., n-undecane, n-dodecane, $n$-tridecane, $n$-tetradecane, and $n$ pentadecane) are often referred to in Hanford site literature as the normal paraffinic hydrocarbons (NPHs). Tributyl phosphate itself was detected by ORNL in TST samples, as well as dibutyl butylphosphonate, a common contaminant present from the manufacture of tributyl phosphate. It is also likely that the tentatively identified semivolatile branched alkanes were also introduced with the NPHs as waste.

The concentrations of the NPHs in the tank A-101 headspace are too high and the solubilities of the NPHs in aqueous wastes are too small to assume that they are dissolved in the aqueous waste of tank A-101. An organic liquid phase of some sort probably exists, though wether it resides as a small puddle or is lightly smeared over different parts of the tank and waste can not be determined from vapor samples. The headspace concentrations of these semivolatile constituents depend on the amount of organic-phase surface area, the temperature of the organic-phase, and the ventilation rate of the tank.

Though the NPHs are not present at high concentrations in the headspace of tank A-101, they are thought to be the precursors of most of the other organic compounds identified in tank A-101. Condensed phase chemical and radiolytic reactions degrade the NPHs into shorter carbon chain molecules, such as the volatile nitriles, aldehydes, alcohols, and alkenes. The abundance of these in the headspace probably depends on their generation rates and the tank ventilation rate, because they are relatively volatile, and probably do' not remain in the organic liquid phase in significant concentrations. Other degradation products of the NPHs may include non-volatile acids (which would be converted to salts on contact with the aqueous waste), and high-molecular weight compounds with very low volatilities.

Several chlorinated solvents were identified in the tank A-101 vapor samples. 1,1-Dichloroethene, dichloromethane (methylene chloride), and tetrachloroethene were all positiveiy identified by PNL. These have been used as industrial solvents, and may have been added to the tank in small quantities when they became radiologically contaminated. The other positively identified halogenated compound, trichlorofluoromethane, is a freon (and not really a solvent), with a boiling point of about $23^{\circ} \mathrm{C}$. The source of this is not known, but it is frequently detected in the waste tank headspaces. One plausible explanation for its presence is that it was the gas component of urethane foam that was used to seal concrete pit covers on the tanks. Whether this type of foam was used on tank A-101 has not been determined.

The total organic vapor concentration in PNL TST and SUMMA ${ }^{\mathrm{TM}}$ canister samples was determined (by $\mathrm{GC} / \mathrm{MS}$ ) to be $12.5 \mathrm{mg} / \mathrm{m}^{3}$ and $25.3 \mathrm{mg} / \mathrm{m}^{3}$, respectively (Pool et al. 1995). These estimates differ primarily because of the relatively high concentration of 1 -butanol, $13.6 \mathrm{mg} / \mathrm{m}^{3}$, found in SUMMA ${ }^{\text {TM }}$ canister samples. A similar summation of semiquantitative and estimated organic vapor concentrations reported by ORNL from TST analyses (also by GC/MS) gave an estimated $19 \mathrm{mg} / \mathrm{m}^{3}$ of organic vapors (Jenkins et al. 1995).

In general, the organic vapors in tank A-101 are similar to those observed in other passively ventilated waste tanks at the Hanford site. On the basis of mass concentrations, alcohols are the dominate type of organic compound in the tank A-101. The estimated total organic vapor concentration, ranging from 13.6 to $25.3 \mathrm{mg} / \mathrm{m}^{3}$, is moderately high compared to other passively ventilated tanks that have been sampled. 


\section{WHC-SD-WM-ER-505 Rev. 0}

\subsection{SUMMARY}

The tank A-101 headspace was sampled in June 1995 for gases and vapors to address flammability and industrial hygiene concerns. Results of sample collection and analysis have been reported. It was determined that no headspace constituents exceeded the flammability notification limit, but that ammonia, specified in the current $754 \mathrm{ppmv}$, did exceed its $150 \mathrm{ppmv}$ industrial hygiene notification limit specified in the current Vapor Sampling and Analysis Plan (Homi 1995b).

$$
\text { is }
$$




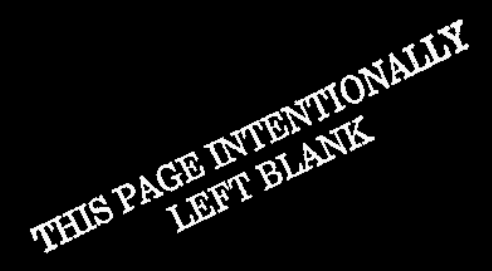


WHC-SD-WM-ER-505 Rev. 0

\subsection{REFERENCES}

29 CFR 1910.120, 1993, "Hazardous Waste Operations and Emergency Response", Code of Federal Regulations.

Bumum, S. T., 1995, Qualification of Reported WHC Vapor Program Data, (letter 95-CHD-065 to president, Westinghouse Hanford Company, August 18), Department of Energy, Richland Operations Office, Richland, Washington.

Cashdollar, K. L.,,M. Hertzberg, I. A. Zlochower, C. E. Lucci, G. M. Green, and R. A. Thomas, 1992, Laboratory Flammability Studies of Mixtures of Hydrogen, Nitrous Oxide, and Air, WHC-SD-WMES-219 Rev. 0, Westinghouse Hanford Company, Richland, Washington.

Dougherty, L. F., 1995, Single Shell Tank Interim Operational Safety Requirements, WHC-SD-WM-OSR005 Rev. 0, Westinghouse hanford company, Richland, Washington.

EPA 1988, Compendium of Methods for the Determination of Toxic Organic Compounds in Ambient Air, PB90-127374, U.S. Environmental Protection Agency, Washington, D.C.

EPA 1992, Test Methods for Evaluating Solid Waste, SW-846 Rev. 1, U.S. Environmental Protection Agency, Washington, D.C.

Hendrickson, R. W., 1995, Tank Vapor Characterization Oak Ridge National Laboratories Quality Assurance Assessment, TWRSQA-95-0012, Westinghouse Hanford Company, Richland, Washington.

Homi, C. S., 1995a, Tank 241-A-101 Tank Characterization Plan, WHC-SD-WM-TP-331 Rev. 0, Westinghouse Hanford Company, Richland, Washington.

Homi, C. S., 1995b, Vapor Sampling and Analysis Plan, WHC-SD-WM-TP-335 Rev. 0G, Westinghouse Hanford Company, Richland, Washington.

Huckaby, J. L., 1994, Tank 241-C-103 Headspace Flammability, WHC-EP-0734 Rev. 1, Westinghouse Hanford Company, Richland, Washington.

Huckaby, J. L., H. Babad, and D. R. Bratzel, 1995, Headspace Gas and Vapor Characterization Summary for the 43 Vapor Program Suspect Tanks, WHC-SD-WM-ER-514 Rev. 0, Westinghouse Hanford Company, Richland, Washington.

Huckaby, J. L., and M. S. Story, 1994, Vapor Characterization of Tank 241-C-103, WHC-EP-0780 Rev. 0, Westinghouse Hanford Company, Richland, Washington.

Jenkins, R. A, A. B. Dindal, C. Y. Ma, M. A. Palausky, J. T. Skeen, and C. K. Bayne, 1995, Analysis of Tank 241-A-101 Headspace Components, ORNL-CASD-FR-241A101.95 Rev. 0, Oak Ridge National Laboratory, Oak Ridge, Tennessee.

Keller, K. K., 1994, Quality Assurance Project Plan for Tank Vapor Characterization, WHC-SD-WMQAPP-013 Rev. 2, Westinghouse Hanford Company, Richland, Washington. 
Klinger, G. S., T. W. Clauss, M. W. Ligotke, K. H. Pool, R. B. Lucke, B. D. MoVeety, O. P. Bredt, J. S. Young, M. McCulloch, J. S. Fruchter, and S. C. Goheen, 1995, Vapor Space Characterization of Waste Tank 241-TX-105: Results from Samples Collected Through the Vapor Sampling System on 12/20/94, PNL-10594 UC-606, Pacific Northwest Laboratory, Richland, Washington.

Ligotke, M. W., K. H. Pool, T. W. Clauss, B. D. McVeety, G. S. Klinger, K. B. Olsen, O. P. Bredt, J. S. Fruchter, and S. C. Goheen, 1995, Vapor Space Characterization of Waste Tank 241-U-103: Results from Samples Collected on 2/15/95, PNL-10813 UC-606, Pacific Northwest Laboratory, Richland, Washington.

Lucke, R. B., M. W. Ligotke, K. H. Pool, T. W. Clauss, A. K. Sharma, B. D. MoVeety, M. Moculloch, J. S. Fruchter, and S. C. Goheen, 1995, Vapor Space Characterization of Waste Tank 241-C-108: Results from Samples Collected Through the Vapor Sampling System on 8/5/94, PNL-10351 UC606, Pacific Northwest Laboratory, Richland, Washington.

Mahlum, D. D., J. Y. Young, and R. E. Weller, 1994, Toxicologic Evaluation of Analytes from Tank 231-C103, PNL-10189, Pacific Northwest Laboratory, Richland, Washington.

McVeety, B. D., T. W. Clauss, M. W. Ligotke, K. H. Pool, R. B. Lucke, G. S. Klinger, J. S. Young, M. McCulloch, J. S. Fruchter, and S. C. Goheen, 1995, Vapor Space Characterization of Waste Tank 241-BY-108: Results from Samples Collected on 10/27/94, PNL-10495 UC-606, Pacific Northwest Laboratory, Richland, Washington.

Meacham, J. E., H. Babad, R. J. Cash, G. T. Dukelow, S. J. Eberlein, D. W. Hamilton, G. D. Johnson, J. W. Osborne, M. A. Payne, D. J. Shenwood, D. A. Turner, and J. L. Huckaby, 1995, Approach for Tank Safety Characterization of Hanford Site Waste, WHC-EP-0843 Rev. 0, UC-2070, Westinghouse Hanford Company, Richland, Washington.

NFPA 1992, Standard on Explosion Prevention Systems, NFPA 69, National Fire Protection Association, Quincy, Massachusetts.

Osborne, J. W., and J. L. Huckaby, 1994, Program Plan for the Resolution of Tank Vapor Issues, WHCEP-0562 Rev. 1, Westinghouse Hanford Company, Richland, Washington.

Osborne, J. W., J. L. Huckaby, T. P. Rudolph, E. R. Hewitt, D. D. Mahlum, J. Y. Young, and C. M. Anderson, 1995, Data Quality Objectives for Generic In-Tank Health and Safety Issue Resolution, WHC-SD-WM-DQO-002 Rev. 1, Westinghouse Hanford Company, Richland, Washington.

Pool, K. H., T. W. Clauss, M. W. Ligotke, B. D. MoVeety, K. B. Olsen, J. S. Fruchter, and S. C. Goheen, 1995, Vapor Space Characterization of Waste Tank 241-A-101: Results from Samples Collected on 6/8/95, PNL-10808 UC-606, Pacific Northwest Laboratory, Richland, Washington.

WHC 1995a, Operating Specifications for Watchlist Tanks, OSD-T-151-00030, Rev. B-9, Westinghouse Hanford Company, Richland, Washington.

WHC 1995b, Vapor and Gas Sampling of Single-Shell Tank 241-A-101 Using the Vapor Sampling System, WHC-SD-WM-RPT-169, Westinghouse Hanford Company, Richland, Washington. 
WHC-SD-WM-ER-505 Rev. 0

Table 2-1

Tank A-101 Gas and Vapor Sample Type and Number

\begin{tabular}{|c|c|c|c|c|}
\hline Laboratory & Sampling Device & $\begin{array}{c}\text { Nominal Sample } \\
\text { Volume (L) }\end{array}$ & Target Analytes & Number of Samples \\
\hline $\begin{array}{l}\text { Oak Ridge National } \\
\text { Laboratories }\end{array}$ & Triple Sorbent Trap & $\begin{array}{l}0.2 \\
1.0 \\
4.0\end{array}$ & $\begin{array}{l}\text { Organic vapors } \\
\text { Organic vapors } \\
\text { Organic vapors }\end{array}$ & $\begin{array}{l}4 \text { tank air samples } \\
4 \text { tank air samples } \\
4 \text { tank air samples } \\
+2 \text { trip blanks } \\
+2 \text { field blanks }\end{array}$ \\
\hline \multirow[t]{6}{*}{$\begin{array}{l}\text { Pacific Northwest } \\
\text { Laboratories }\end{array}$} & $\begin{array}{l}\text { Acidified Carbon Sorbent } \\
\text { Trap }\end{array}$ & 3.0 & Ammonia & $\begin{array}{l}6 \text { tank air samples } \\
+3 \text { trip blank }\end{array}$ \\
\hline & $\begin{array}{l}\text { Triethanolamine Sorbent } \\
\text { Trap }\end{array}$ & 3.0 & Nitrogen Dioxide & $\begin{array}{l}6 \text { tank air samples } \\
+3 \text { trip blank }\end{array}$ \\
\hline & $\begin{array}{l}\text { Oxidation Bed }+ \\
\text { Triethanolamine Sorbent } \\
\text { Trap }\end{array}$ & 3.0 & Nitric Oxide & $\begin{array}{l}6 \text { tank air samples } \\
+3 \text { trip blank }\end{array}$ \\
\hline & Silica Gel Sorbent Trap & 3.0 & Water vapor & $\begin{array}{l}6 \text { tank air samples } \\
+3 \text { trip blanks }\end{array}$ \\
\hline & SUMMA ${ }^{T M}$ canister & 6.0 & $\begin{array}{l}\text { Carbon Dioxide, } \\
\text { Carbon Monoxide, } \\
\text { Hydrogen, Methane, } \\
\text { Nitrous Oxide, Organic } \\
\text { vapors }\end{array}$ & $\begin{array}{c}3 \text { tank air samples + } 2 \\
\text { ambient air samples } \\
\end{array}$ \\
\hline & Triple Sorbent Trap & $\begin{array}{l}0.2 \\
1.0 \\
4.0\end{array}$ & $\begin{array}{l}\text { Organic vapors } \\
\text { Organic vapors } \\
\text { Organic vapors }\end{array}$ & $\begin{array}{l}4 \text { tank air samples } \\
4 \text { tank air samples } \\
4 \text { tank air samples } \\
+2 \text { trip blanks } \\
+2 \text { field blanks }\end{array}$ \\
\hline
\end{tabular}




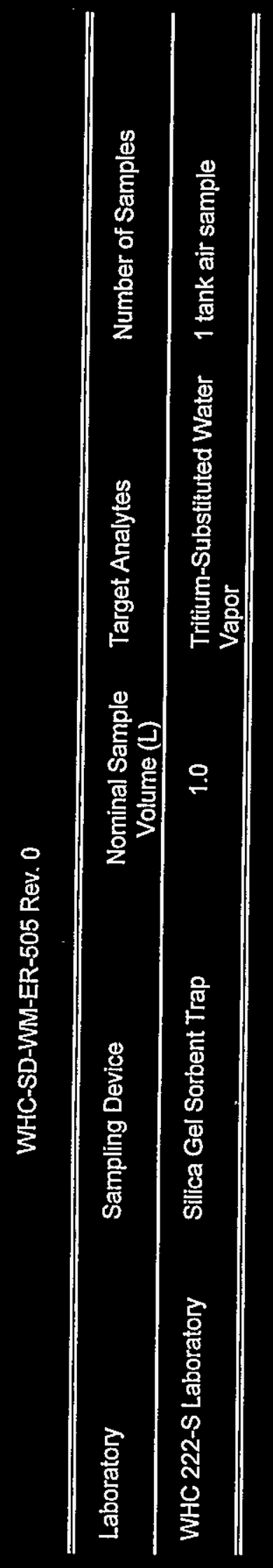




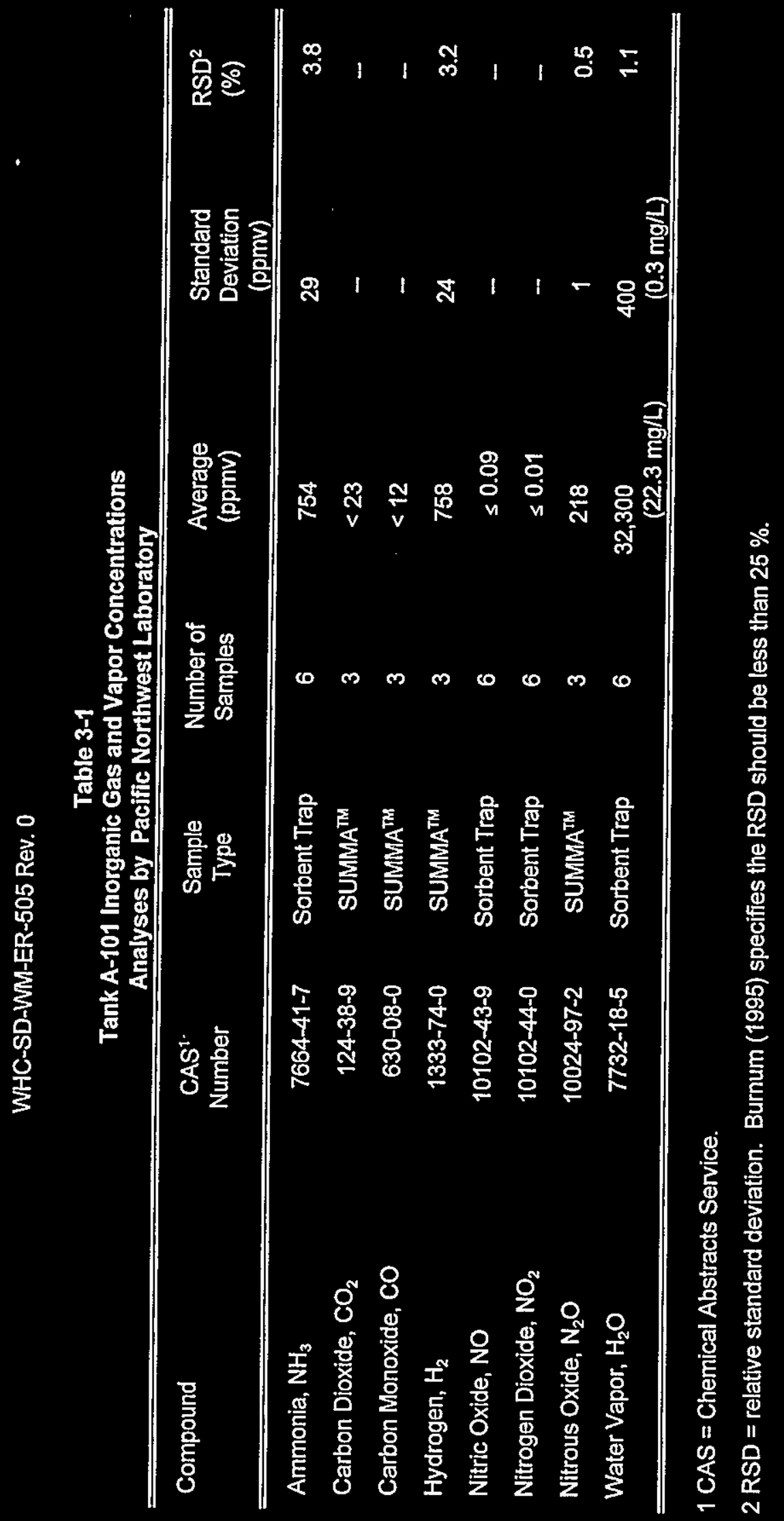




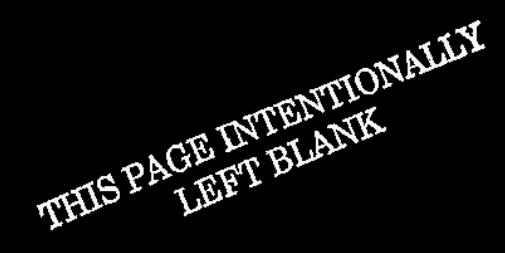


WHC-SD-WM-ER-505 REv. 0

Table 4-1

Tank A-101 Quantitatively Measured Compounds in SUMMA ${ }^{\text {TM }}$ Samples Analyses by Pacific Northwest Laboratory

\begin{tabular}{clcccc}
\hline $\begin{array}{c}\text { Cmpd } \\
\#\end{array}$ & Compound & $\begin{array}{c}\text { CAS }^{1} \\
\text { Number }\end{array}$ & $\begin{array}{c}\text { Average } \\
(\text { ppmv) }\end{array}$ & $\begin{array}{c}\text { Standard } \\
\text { Deviation } \\
\text { (ppmv) }\end{array}$ & $\begin{array}{c}\text { RSD }^{3} \\
(\%)\end{array}$ \\
\hline 1 & Ethanenitrile (acetonitrile) & $75-05-8$ & 0.057 & 0.004 & 6 \\
2 & Propanone (acetone) & $67-64-1$ & 0.72 & 0.02 & 2 \\
3 & Trichlorofluoromethane & $75-69-4$ & 0.057 & 0.002 & 3 \\
4 & Propanenitrile & $107-12-0$ & 0.016 & 0.0002 & 2 \\
5 & 1-Propanol & $71-23-8$ & 0.069 & 0.003 & 5 \\
6 & 2-Butanone & $78-93-3$ & 0.084 & 0.001 & 2 \\
7 & Tetrahydrofuran & $109-99-9$ & 0.16 & 0.002 & 1 \\
8 & Benzene & $71-43-2$ & 0.007 & 0.0001 & 1 \\
9 & n-Heptane & $142-82-5$ & 0.019 & 0.0002 & 1 \\
10 & Pyridine & $110-86-1$ & 0.007 & 0.0005 & 6 \\
11 & Toluene & $108-88-3$ & 0.011 & 0.0001 & 1 \\
12 & Tetrachloroethylene & $127-18-4$ & 0.011 & 0.0002 & 2 \\
$13 \&$ & 1,3-Dimethylbenzene (m-xylene) + & $108-38-3$ & 0.005 & 0.0001 & 1 \\
14 & 1,4-Dimethylbenzene (p-xylene) & $106-42-3$ & & & - \\
15 & Methane & $74-82-8$ & $<12$ & - \\
\hline
\end{tabular}

$1 \mathrm{CAS}=$ Chemical Abstract Service.

2 Average of 3 samples.

3 RSD = relative standard deviation. Burnum (1995) specifies the RSD should be less than $25 \%$.

$4 \mathrm{~m}$-xylene and $\mathrm{p}$-xylene coelute and the reported value represents the sum of their concentrations. 
Table 4-2

Tank A-101 Quantitatively Measured Compounds in TST Samples Analyses by Pacific Northwest Laboratory

\begin{tabular}{|c|c|c|c|c|c|}
\hline Cmpd & Compound & $\begin{array}{l}\text { CAS }^{1} \\
\text { Number }\end{array}$ & $\begin{array}{c}\text { Average }^{2} \\
\text { (ppmv) }\end{array}$ & $\begin{array}{c}\text { Standard } \\
\text { Deviation } \\
\text { (ppmv) }\end{array}$ & $\begin{array}{c}\mathrm{RSD}^{3,4} \\
(\%)\end{array}$ \\
\hline 1 & Dichlorodifiluoromethane & $75-71-8$ & 0.010 & 0.001 & 10 \\
\hline 2 & Chloromethane & $74-87-3$ & 0.018 & 0.007 & 39 \\
\hline 3 & Ethanenitrile (acetonitrile) & $75-05-8$ & 0.050 & 0.021 & 42 \\
\hline 4 & Propanone (acetone) & $67-64-1$ & 0.18 & 0.02 & 11 \\
\hline 5 & Trichlorofluoromethane & $75-69-4$ & 0.072 & 0.027 & 38 \\
\hline 6 & 1,1-Dichloroethene ${ }^{5}$ & $75-35-4$ & 0.0066 & 0.0005 & 7 \\
\hline 7 & Dichloromethane (methylene chloride) & $75-09-2$ & 0.012 & 0.006 & 50 \\
\hline 8 & Propanenitrile & $107-12-0$ & 0.019 & 0.004 & 21 \\
\hline 9 & 1-Propanol & $71-23-8$ & 0.15 & 0.02 & 15 \\
\hline 10 & 2-Butanone & $78-93-3$ & 0.039 & 0.011 & 28 \\
\hline 11 & Tetrahydrofuran & $109-99-9$ & 0.10 & 0.01 & 11 \\
\hline 12 & n-Butanenitrile & $109-74-0$ & 0.012 & 0.003 & 25 \\
\hline 13 & Benzene & $71-43-2$ & 0.013 & 0.005 & 38 \\
\hline 14 & n-Heptane & $142-82-5$ & 0.020 & 0.001 & 5 \\
\hline 15 & Pyridine & $110-86-1$ & 0.0085 & 0.0002 & 2 \\
\hline 16 & Toluene & $108-88-3$ & 0.014 & 0.002 & 14 \\
\hline 17 & Tetrachloroethylene & $127-18-4$ & 0.013 & 0.0003 & 2 \\
\hline $\begin{array}{c}18 \& \\
19 \\
\end{array}$ & $\begin{array}{l}\text { 1,3-Dimethylbenzene (m-xylene) }+ \\
\text { 1,4-Dimethylbenzene (p-xylene })^{6}\end{array}$ & $\begin{array}{l}108-38-3 \\
106-42-3 \\
\end{array}$ & 0.0073 & 0.0005 & 7 \\
\hline
\end{tabular}

$1 \mathrm{CAS}=$ Chemical Abstract Service.

2 Average of 3 samples.

3 RSD = relative standard deviation. Burnum (1995) specifies the RSD should be less than $25 \%$.

4 When the analyte was detected in only 2 samples, the entry is the relative difference (i.e., their difference divided by 2 ).

5 Detected in only 2 samples.

$6 \mathrm{~m}$-xylene and $p$-xylene coelute and the reported value represents the sum of their concentrations. 
WHC-SD-WM-ER-505 Rev. 0

Table 4-3

Tank A-101 Comparison of Organic Compounds in TST and SUMMA TM Samples Analyses by Pacific Northwest Laboratory

\begin{tabular}{|c|c|c|c|c|c|}
\hline$\underset{\#}{\text { Cmpd }}$ & Compound & $\begin{array}{l}\text { CAS }^{1} \\
\text { Number }\end{array}$ & $\begin{array}{c}\text { TST } \\
\text { Average }^{2} \\
\text { (ppmv) }\end{array}$ & $\begin{array}{c}\text { SUMMA } \\
\text { Average }^{3} \\
\text { (ppmv) }\end{array}$ & $\begin{array}{l}\mathrm{RPD}^{4} \\
(\%)\end{array}$ \\
\hline 1 & Dichlorodifluoromethane & $75-71-8$ & 0.010 & $<0.005$ & - \\
\hline 2 & Chloromethane & $74-87-3$ & 0.018 & $<0.005$ & - \\
\hline 3 & Ethanenitrile (acetonitrile) & $75-05-8$ & 0.050 & 0.057 & -13 \\
\hline 4 & Propanone (acetone) & $67-64-1$ & 0.18 & 0.72 & -120 \\
\hline 5 & Trichlorofluoromethane & $75-69-4$ & 0.072 & 0.057 & 23 \\
\hline 6 & 1,1-Dichloroethene 5 & $75-35-4$ & 0.0066 & $<0.005$ & - \\
\hline 7 & Dichloromethane (methylene chloride) & $75-09-2$ & 0.012 & $<0.005$ & - \\
\hline 8 & Propanenitrile & $107-12-0$ & 0.019 & 0.016 & 17 \\
\hline 9 & Propanol & $71-23-8$ & 0.15 & 0.069 & 74 \\
\hline 10 & 2-Butanone & $78-93-3$ & 0.039 & 0.084 & -73 \\
\hline 11 & Tetrahydrofuran & $109-99-9$ & 0.10 & 0.16 & -46 \\
\hline 12 & n-Butanenitrile & 109-74-0 & 0.012 & $<0.005$ & - \\
\hline 13 & Benzene & $71-43-2$ & 0.013 & 0.007 & 60 \\
\hline 14 & n-Heptane & $142-82-5$ & 0.020 & 0.019 & 5 \\
\hline 15 & Pyridine & $110-86-1$ & 0.0085 & 0.007 & 19 \\
\hline 16 & Toluene & $108-88-3$ & 0.014 & 0.011 & 24 \\
\hline 17 & Tetrachloroethylene & $127-18-4$ & 0.013 & 0.011 & 17 \\
\hline $\begin{array}{r}18 \& \\
19 \\
\end{array}$ & $\begin{array}{l}\text { 1,3-Dimethylbenzene (m-xylene) }+ \\
\text { 1,4-Dimethylbenzene (p-xylene) })^{6}\end{array}$ & $\begin{array}{l}108-38-3 \\
106-42-3 \\
\end{array}$ & 0.0073 & 0.005 & 37 \\
\hline
\end{tabular}

$1 \mathrm{CAS}=$ Chemical Abstract Service.

2 Average of 3 TST sample analyses by PNL.

3 Average of 3 SUMMA ${ }^{\text {TM }}$ sample analyses by PNL.

$4 \mathrm{RPD}=$ relative percent difference (i.e., the difference divided by the mean of the 2 values).

5 Detected in only 2 samples.

$6 \mathrm{~m}$-xylene and $\mathrm{p}$-xylene coelute and the reported value represents the sum of their concentrations. 
WHC-SD-WM-ER-505 Rev. 0

Table 4-4

Tank A-101 Quantitatively Measured Organic Analytes in TST Samples-Analyses by Oak Ridge National Laboratory'

\begin{tabular}{clcccc}
\hline $\begin{array}{c}\text { Cmpd } \\
\#\end{array}$ & Compound & $\begin{array}{c}\text { CAS }^{2} \\
\text { Number }\end{array}$ & $\begin{array}{c}\text { Average } \\
\text { (ppmv) }\end{array}$ & $\begin{array}{c}\text { Standard } \\
\text { Deviation } \\
\text { (ppmv) }\end{array}$ & $\begin{array}{c}\text { RSD }^{4} \\
(\%)\end{array}$ \\
\hline \hline 1 & Ethanenitrile (acetonitrile) & $75-05-8$ & 0.16 & 0.03 & 19 \\
2 & Propanenitrile & $107-12-0$ & 0.034 & 0.004 & 13 \\
3 & n-Hexane & $110-54-3$ & 0.0088 & 0.0006 & 7 \\
4 & n-Butanenitrile & $109-74-0$ & 0.022 & 0.004 & 20 \\
5 & 2-Pentanone & $107-87-9$ & 0.015 & 0.003 & 18 \\
6 & n-Heptane & $142-82-5$ & 0.022 & 0.001 & 6 \\
7 & Toluene & $108-88-3$ & 0.0097 & 0.0006 & 7 \\
8 & 2-Hexanone & $591-78-6$ & 0.019 & 0.004 & 19 \\
9 & 2-Heptanone & $110-43-0$ & 0.030 & 0.005 & 17 \\
10 & n-Undecane & $1120-21-4$ & 0.014 & 0.001 & 8 \\
11 & n-Dodecane & $112-40-3$ & 0.048 & 0.003 & 6 \\
\hline \hline
\end{tabular}

1 Results in this table are quantitative (as defined in Section 4.1).

$2 \mathrm{CAS}=$ Chemical Abstract Service.

3 Average of 3, 1-L TST samples.

4 RSD = relative standard deviation. Burnum (1995) specifies the RSD should be less than $25 \%$. 
WHC-SD-WM-ER-505 Rev. 0

Table 4-5

Tank A-101 Positively Identified Organic Analytes in TST Samples-Analyses by Oak Ridge National Laboratory ${ }^{1}$

\begin{tabular}{clcccc}
\hline $\begin{array}{c}\text { Cmpd } \\
\#\end{array}$ & Compound & $\begin{array}{c}\text { CAS }^{2} \\
\text { Number }\end{array}$ & $\begin{array}{c}\text { Average } \\
\text { (ppmv) }\end{array}$ & $\begin{array}{c}\text { Standard } \\
\text { Deviation } \\
\text { (ppmv) }\end{array}$ & $\begin{array}{c}\text { RSD }^{4} \\
(\%)\end{array}$ \\
\hline \hline 1 & Propanone (acetone) & $67-64-1$ & 0.29 & 0.06 & 21 \\
2 & 1,1-Dichloroethene (vinylidene chloride) & $75-35-4$ & 0.0011 & 0.0002 & 20 \\
3 & Benzene & $71-43-2$ & 0.0067 & 0.0001 & 1 \\
4 & n-Pentanenitrile & $110-59-8$ & 0.0072 & 0.0010 & 15 \\
5 & n-Octane & $111-65-9$ & 0.0024 & 0.0004 & 17 \\
6 & n-Hexanenitrile & $628-73-9$ & 0.0019 & 0.0004 & 22 \\
7 & n-Nonane & $111-84-2$ & 0.0037 & 0.0003 & 7 \\
8 & n-Heptanenitrile & $629-08-3$ & 0.0010 & 0.0002 & 17 \\
9 & 2-Octanone & $111-13-7$ & 0.0030 & 0.0005 & 16 \\
10 & n-Decane & $124-18-5$ & 0.0027 & 0.0002 & 10 \\
11 & n-Tridecane & $629-50-5$ & 0.10 & 0.01 & 6 \\
\hline \hline
\end{tabular}

1 Results in this table are not quantitative (as defined in Section 4.1) because measured values in at least 1 of the samples are outside instrument calibration limits.

$2 \mathrm{CAS}=$ Chemical Abstract Service.

3 Average of 3, 1-L TST samples.

4 RSD = relative standard deviation. Burnum (1995) specifies the RSD should be less than $25 \%$. 
WHC-SD-WM-ER-505 Rev. 0

Table 4-6

Tank A-101 Positively Identified Organic Analytes in TST Samples for which Practical Holding Times were Exceeded -Analyses by Oak Ridge National Laboratory'

\begin{tabular}{clcccc}
\hline $\begin{array}{c}\text { Cmpd } \\
\#\end{array}$ & Compound & $\begin{array}{c}\text { CAS }^{2} \\
\text { Number }\end{array}$ & $\begin{array}{c}\text { Average } \\
\text { (ppmv) }\end{array}$ & $\begin{array}{c}\text { Standard } \\
\text { Deviation } \\
\text { (ppmv) }\end{array}$ & $\begin{array}{c}\text { RSD }^{4} \\
(\%)\end{array}$ \\
\hline \hline 1 & Butanal $^{5}$ & $123-72-8$ & 0.48 & 0.01 & 3 \\
2 & $1-$ Butanol $^{5}$ & $71-36-3$ & 2.5 & 0.2 & 10 \\
\hline \hline
\end{tabular}

1 Practical holding times are defined and discussed in Section 4.1.

$2 \mathrm{CAS}=$ Chemical Abstract Service.

3 Average of 3, 1-L TST samples.

4 RSD = relative standard deviation. Burnum (1995) specifies the RSD should be less than $25 \%$.

5 The concentration of this analyte was not quantitatively measured (as defined in Section 4.1), because the measured concentration was outside of the instrumental calibration limits. 
WHC-SD-WM-ER-505 Rev. 0

Table 4-7

Tank A -101 Comparison of Positively Identified Organic Compounds Analyses by Pacific Northwest Laboratory and Oak Ridge National Laboratory

\begin{tabular}{lcccc}
\hline Compound & $\begin{array}{c}\text { CAS }^{1} \\
\text { Number }\end{array}$ & $\begin{array}{c}\text { PNL SUMMA } \\
\text { Average }^{2} \\
\text { (ppmv) }\end{array}$ & $\begin{array}{c}\text { PNL TST } \\
\text { Average }^{3} \\
\text { (ppmv) }\end{array}$ & $\begin{array}{c}\text { ORNL TST } \\
\text { Average }^{4} \\
\text { (ppmv) }\end{array}$ \\
\hline \hline $\begin{array}{l}\text { Ethanenitrile (acetonitrile) } \\
\text { Propanone (acetone) }\end{array}$ & $75-05-8$ & 0.057 & 0.050 & 0.16 \\
1,1-Dichloroethene & $67-64-1$ & 0.72 & 0.18 & 0.29 \\
Dichloromethane & $75-35-4$ & $<0.005$ & 0.0066 & 0.0011 \\
Propanenitrile & $75-09-2$ & $<0.005$ & 0.012 & $<0.005$ \\
n-Butanenitrile & $107-12-0$ & 0.016 & 0.019 & 0.034 \\
Benzene & $109-74-0$ & $<0.005$ & 0.012 & 0.022 \\
n-Heptane & $71-43-2$ & 0.007 & 0.013 & 0.0067 \\
Toluene & $142-82-5$ & 0.019 & 0.020 & 0.022 \\
n-Decane & $108-88-3$ & 0.011 & 0.014 & 0.0097 \\
\hline \hline
\end{tabular}

$1 \mathrm{CAS}=$ Chemical Abstract Service.

2 Average of 3 sample analyses.

3 Average of 3 TST sample analyses by PNL.

4 Average of $3,1-L$ TST sample analyses by ORNL. 
WHC-SD-WM-ER-505 Rev. 0

Table 4-8

Tank A-101 Tentatively Identified Compounds in SUMMA ${ }^{\text {TM }}$ Samples -Analyses by Pacific Northwest Laboratory

\begin{tabular}{|c|c|c|c|c|}
\hline Cmpd & Compounds & $\begin{array}{c}\mathrm{CAS}^{1} \\
\text { Number }\end{array}$ & $\begin{array}{l}\text { Average }^{2} \\
\left(\mathrm{mg} / \mathrm{m}^{3}\right)\end{array}$ & $\begin{array}{c}\text { Standard } \\
\text { Deviation } \\
\left(\mathrm{mg} / \mathrm{m}^{3}\right) \\
\end{array}$ \\
\hline 1 & Propene & $115-07-1$ & 0.53 & 0.01 \\
\hline 2 & Unknown & & 0.36 & 0.02 \\
\hline 3 & Methyl nitrite & $624-91-9$ & 0.87 & 0.27 \\
\hline 4 & Cyclopropane & $75-19-4$ & 0.29 & 0.03 \\
\hline 5 & Methanol (methyl alcohol) & $67-56-1$ & 1.80 & 0.03 \\
\hline 6 & Unknown C4 Alkene/Cycloalkane & & 0.38 & 0.02 \\
\hline 7 & 1,3-Butadiene & $106-99-0$ & 0.26 & 0.01 \\
\hline 8 & n-Butane & $106-97-8$ & 0.25 & 0.01 \\
\hline 9 & 1-Propene, 2-methyl- & $115-11-7$ & 0.076 & 0.005 \\
\hline 10 & Ethanol & $64-17-5$ & 0.64 & 0.03 \\
\hline 11 & 2-Propanol (isopropyl alcohol) & $67-63-0$ & 0.25 & 0.02 \\
\hline 12 & n-Pentane & $109-66-0$ & 0.11 & 0.002 \\
\hline 13 & Unknown & & 0.10 & 0.02 \\
\hline 14 & Butanal & $123-72-8$ & 0.73 & 0.01 \\
\hline 15 & 2-Butanol ${ }^{4}$ & $78-92-2$ & 0.061 & - \\
\hline 16 & Unknown & & 0.065 & 0.003 \\
\hline 17 & 1-Butanol & $71-36-3$ & 13.6 & 1.1 \\
\hline 18 & 2-Pentanone & $107-87-9$ & 0.097 & 0.003 \\
\hline 19 & Pentanal ${ }^{4}$ & $110-62-3$ & 0.052 & - \\
\hline 20 & 2-Hexanone & $591-78-6$ & 0.062 & 0.001 \\
\hline 21 & 4-Heptanone & $123-19-3$ & 0.054 & 0.004 \\
\hline 22 & 3-Heptanone & $106-35-4$ & 0.53 & 0.01 \\
\hline 23 & 2-Heptanone & $110-43-0$ & 0.088 & 0.002 \\
\hline 24 & Unknown & & 0.054 & 0.002 \\
\hline 25 & Unknown & & 0.066 & 0.002 \\
\hline 26 & Unknown & & 0.063 & 0.003 \\
\hline
\end{tabular}


WHC-SD-WM-ER-505 Rev. 0

\begin{tabular}{rlrll}
27 & 1-Hexanol, 2-ethyl- & $104-76-7$ & 0.11 & 0.03 \\
28 & n-Undecane & $1120-21-4$ & 0.057 & 0.003 \\
29 & n-Dodecane & $112-40-3$ & 0.09 & 0.006 \\
30 & n-Tridecane & 0.091 & 0.007 \\
\hline \hline Sum of tentatively identified compounds: & $629-50-5$ & 0.091 \\
\hline \hline
\end{tabular}

$1 \mathrm{CAS}=$ Chemical Abstract Service.

2 Based on analyses of 3 samples. Values given are estimates.

3 When the analyte was detected in only 2 samples, the entry is the average difference (i.e., their difference divided by 2).

4 Detected in only 1 sample.

5 Detected in only 2 samples. 
WHC-SD-WM-ER-505 Rev. 0

Table 4-9

Tank A-101 Tentatively Identified Compounds in TST Samples Analyses by Pacific Northwest Laboratory

\begin{tabular}{|c|c|c|c|c|}
\hline$\underset{\#}{\text { Cmpd }}$ & Compounds & $\begin{array}{l}\text { CAS }^{1} \\
\text { Number }\end{array}$ & $\begin{array}{c}\text { Average }^{2} \\
\left(\mathrm{mg} / \mathrm{m}^{3}\right)\end{array}$ & $\begin{array}{c}\text { Standard } \\
\text { Deviation } \\
\left(\mathrm{mg} / \mathrm{m}^{3}\right)\end{array}$ \\
\hline 1 & Methanol (methyl alcohol) & $67-56-1$ & 0.45 & 0.46 \\
\hline 2 & Ethanol & $64-17-5$ & 0.28 & 0.2 \\
\hline 3 & Unknown ${ }^{4}$ & & 0.63 & - \\
\hline 4 & n-Pentane ${ }^{4}$ & $109-66-0$ & 0.031 & - \\
\hline 5 & Unknown ${ }^{4}$ & & 0.058 & - \\
\hline 6 & Butanal $^{4}$ & $123-72-8$ & 0.053 & - \\
\hline 7 & 2-Butanone & $78-93-3$ & 0.13 & 0.04 \\
\hline 8 & 2-Butanol & $78-92-2$ & 0.066 & 0.021 \\
\hline 9 & Acetic acid ${ }^{4}$ & $64-19-7$ & 0.071 & - \\
\hline 10 & 1-Butanol & $71-36-3$ & 3.7 & 0.1 \\
\hline 11 & Propylene Glycol & $57-55-6$ & 0.16 & 0.12 \\
\hline 12 & Pyrazine & $290-37-9$ & 0.056 & 0.004 \\
\hline 13 & Unknown C7 Alkane ${ }^{4}$ & & 0.048 & - \\
\hline 14 & 2-Hexanone & $591-78-6$ & 0.062 & 0.005 \\
\hline 15 & Unknown C8 Alkene/Cycloalkane ${ }^{5}$ & & 0.048 & 0.0015 \\
\hline 16 & Unknown ${ }^{5}$ & & 0.032 & 0.001 \\
\hline 17 & Unknown Methyl Pyridine & & 0.046 & 0.001 \\
\hline 18 & 3-Heptanone & $106-35-4$ & 0.64 & 0.01 \\
\hline 19 & 2-Heptanone & $110-43-0$ & 0.10 & 0.01 \\
\hline 20 & 3-Heptanol & $589-82-2$ & 0.11 & 0.003 \\
\hline 21 & Unknown & & 0.11 & 0.004 \\
\hline 22 & Unknown Ketone & & 0.051 & 0.002 \\
\hline 23 & Formamide, N-butyl- $-^{5}$ & $871-71-6$ & 0.062 & 0.014 \\
\hline 24 & Unknown & & 0.11 & 0.001 \\
\hline 25 & 1-Hexanol, 2-ethyl- & $104-76-7$ & 1.0 & 0.02 \\
\hline 26 & n-Undecane & $1120-21-4$ & 0.12 & 0.003 \\
\hline
\end{tabular}


WHC-SD-WM-ER-505 Rev, 0

\begin{tabular}{|c|c|c|c|c|}
\hline 27 & Unknown & & 0.071 & 0.017 \\
\hline 28 & n-Dodecane & $112-40-3$ & 0.56 & 0.01 \\
\hline 29 & Unknown C13 Alkane & & 0.11 & 0.01 \\
\hline 30 & Cyclohexane, 2-butyl-1,1,3-trimethyl- & $54676-39-0$ & 0.061 & 0.002 \\
\hline 31 & Unknown C10 Alkane & & 0.11 & 0.003 \\
\hline 32 & n-Tridecane & $629-50-5$ & 1.0 & 0.03 \\
\hline 33 & Unknown C15 Alkane & & 0.14 & 0.004 \\
\hline 34 & n-Tetradecane & $629-59-4$ & 0.52 & 0.02 \\
\hline 35 & Unknown C14 Alkane ${ }^{4}$ & & 0.085 & - \\
\hline
\end{tabular}

$1 \mathrm{CAS}=$ Chemical Abstract Service

2 Based on analyses of 3 samples. Values given are estimates. 3 When the analyte was detected in only 2 samples, the entry is the average difference (i.e., their
difference divided by 2 ).

4 Detected in only 1 sample.

5 Detected in only 2 samples. 
Table 4-10

Tank A-101 Tentatively Identified Organic Compounds in TST Samples Analyses by Oak Ridge National Laboratory

\begin{tabular}{|c|c|c|c|c|}
\hline $\begin{array}{c}\text { Cmpd } \\
\#\end{array}$ & Compounds & $\begin{array}{l}\text { CAS }^{1} \\
\text { Number }\end{array}$ & $\begin{array}{c}\text { Average } 2 \\
\left(\mathrm{mg} / \mathrm{m}^{3}\right)\end{array}$ & $\begin{array}{c}\text { Standard } \\
\text { Deviation } \\
\left(\mathrm{mg} / \mathrm{m}^{3}\right)\end{array}$ \\
\hline 1 & 1-Propene, 2-methyl- & $115-11-7$ & 0.10 & 0.09 \\
\hline 2 & Methanol and others & & 0.78 & 0.14 \\
\hline 3 & Ethanol & $64-17-5$ & 0.45 & 0.18 \\
\hline 4 & 2-Propanol (isopropyl alcohol) & $67-63-0$ & 0.16 & 0.03 \\
\hline 5 & 1-Propanol & $71-23-8$ & 0.15 & 0.13 \\
\hline 6 & 2-Butanone & $78-93-3$ & 0.039 & 0.068 \\
\hline 7 & Furan, tetrahydro- & $109-99-9$ & 0.13 & 0.11 \\
\hline 8 & Butane, 1-chloro- & $109-69-3$ & 0.068 & 0.118 \\
\hline 9 & Propylene Glycol & $57-55-6$ & 0.17 & 0.29 \\
\hline 10 & Aziridine, 2-ethyl- & $2549-67-9$ & 0.18 & 0.06 \\
\hline 11 & Tetrachloroethylene & $127-18-4$ & 0.065 & 0.056 \\
\hline 12 & 4-Heptanone & $123-19-3$ & 0.086 & 0.005 \\
\hline 13 & p-Xylene & $106-42-3$ & 0.029 & 0.050 \\
\hline 14 & 3-Heptanone & $106-35-4$ & 0.56 & 0.10 \\
\hline 15 & 3-Heptanol & $589-82-2$ & 0.14 & 0.03 \\
\hline 16 & Furan, 2,5-diethyltetrahydro- & $41239-48-9$ & 0.11 & 0.02 \\
\hline 17 & Cyclotetrasiloxane, octamethyl- & $556-67-2$ & 0.030 & 0.051 \\
\hline 18 & 1-Heptene and others & & 0.12 & 0.01 \\
\hline 19 & 1-Hexanol, 2-ethyl- & $104-76-7$ & 0.87 & 0.09 \\
\hline 20 & Alkenyl-oxo-pyrrolidine & & 0.087 & 0.010 \\
\hline 21 & Undecane, 2,6-dimethyl- & $17301-23-4$ & 0.13 & 0.01 \\
\hline 22 & Undecane, 2,10-dimethyl- & $17301-27-8$ & 0.10 & 0.01 \\
\hline 23 & Tridecane, 7-methyl- & $26730-14-3$ & 0.24 & 0.01 \\
\hline
\end{tabular}


WHC-SD-WM-ER-505 Rev. 0

\begin{tabular}{llrll}
24 & Decane, 2-methyl- & $6975-98-0$ & 0.082 & 0.006 \\
25 & Dodecane, 2,6, 10-trimethyl- & $3891-98-3$ & 0.18 & 0.01 \\
26 & n-Tetradecane & $629-59-4$ & 0.51 & 0.05 \\
27 & Dodecane, 4-methyl- & $6117-97-1$ & 0.12 & 0.04 \\
28 & 3-Tridecanone & $1534-26-5$ & 0.026 & 0.045 \\
29 & n-Pentadecane & $629-62-9$ & 0.17 & 0.10 \\
30 & n-Hexadecane & $544-76-3$ & 0.047 & 0.082 \\
31 & Benzenesulfonamide, N-butyl- & $3622-84-2$ & 0.17 & 0.04 \\
\hline
\end{tabular}

Sum of tentatively identified compounds:

6.1

$1 \mathrm{CAS}=$ Chemical Abstract Service.

2 Based on analyses of 3 samples. Values given are estimates. 
